\title{
TEXT AS A GAME: MODERN STRATEGIES FOR WORKING WITH TEXTS IN FUTURE TEACHERS' TRAINING (ON L. FRANK BAUM'S TALES “AMERICAN TALES")
}

\author{
OLGA DERKACHOVA, OKSANA TYTUN
}

\begin{abstract}
The article deals with modern strategies for working with literature in the future teachers' training process, especially in work with tales. Suggested technologies make it possible to move away from traditional text analysis, to offer interesting interpretations as well as to focus on details. A text comes to life as it receives new interpretations, and visual ones complement the verbal content. This strategy helps make the reading more stimulating. It helps unleash and develop students' analytical and creative potential: interpret scientific texts, create a lapbook and scrapbook. The examples are discussed on the material of Baum's tales, "American Tales", which is a fascinating and original phenomenon of American literature for children, and it provides a considerable space for interpretation. These tales are bright, interesting, and funny and allows to suggest to play with text, details, characters. Such game is impossible without attentive reading and understanding the main ideas of the text. The authors of the given manuscript recommend the following methods of working with texts as calligrams, hero pyramid, mind mapping, six thinking hats by E. Bono, etc. As a result, students begin to read literature more carefully, pay attention to details and better memorize certain episodes. The success of applying holographic technologies in dealing with literature is proved. Thus, the following skills like reading, creative thinking, critical thinking, the ability to express thoughts have been developed as well as the fear of misinterpretation of texts has disappeared.
\end{abstract}

Keywords: literary text, strategies, literary tale, American tale, work with text, interpretation of the text.

\section{INTRODUCTION}

Nowadays visualization appears one of the techniques in text analysis practiced in modern schools. Modern methods of working with literature use the instrumentation of critical thinking taking into account age peculiarities of pupils. We have named our strategies for working with literature as Method of Hologram Projects that provides visualization of works of literature with the help of critical way of thinking. "The active use of innovative teaching methods by teachers is a necessity nowadays. The greater the strategies and methods of teaching the teacher has, the more interesting, diverse it conducts classes, better motivates the student's cognitive activity, shapes the experience of solving nonstandard problems, promotes in-depth training and the steady assimilation of technology of practical activity" [13]. 


\section{THEORETICAL BACKGROUND}

According to the Encyclopedia Britannica, holography is a means of creating a unique photographic image without the use of a lens. The photographic recording of the image is called a hologram, which appears to be an unrecognizable pattern of stripes and whorls but which - when illuminated by coherent light, as by a laser beam - organizes the light into a three-dimensional representation of the original object [7]. In the context of analysis of works of literature, it is a method of showing in a dimensional way both an extract and characters of the text. Holographic method helps decode the structure of the text, the mechanism of co-operation of characters and their nature.

A holographic method is a system of educational facilities and technologies aimed at giving the teaching material in three-dimensional way, it meets the demands of multidimensional perception of environment and supply of life experience [14].

It is a well-known fact that in 1947 Denis Gabor was engaged in making the process of electron microscopy more valuable than the preceding process. At the time of working on the electron microscopy, Gabor conceived the principles of holography. Due to the absence of laser technology in the early stage of holography, Gabor was restricted to the only available source of monochromatic light, which is a lamp. The lamp is comparatively low to the laser in light production. Therefore, the holograms produced at this time were unsatisfactory [11].

In origin and development of holographic technologies, the outstanding role belongs to A. Belkin (1998), L. Kachalova (1991), Z.Kurliand (2014). At the same time, T.Volobuieva offered the application of life technologies with holographic projections at lessons (2007). The application of holographic technologies at lessons was the research subject among the following scientists I.Luyk, K. Polietaieva, V.Soloviov (2017). O.Vorobiova, O.Zhykharieva marked the importance of application of the verbal holography in the literary discourse $(2010,2015)$. They take it as a verbal dimension.

V.Vdovenko considers the application of holographic technologies in studies to be the system of educational methods and technologies aimed at giving new teaching material in a dimensional way that answers the peculiarities of multidimensional perception of the environment and supply of vital experience [16].

\section{Research ObJective, Methodology AND Data}

"Actually, the innovative competence of a modern educator is seen in his ability to use the best European educational technologies in professional practice. Dynamic changes in education in the conditions of its integration into the world educational space puts new challenges to teachers - to be prepared for the effective performance of their professional functions, taking into account innovation" [3]. One of them is to know what to do with text, how to present it, how to make discussion about it bright and interesting. A holographic projection is "information that is possible to find in various sources: in life experience, other knowledge gained from books, mass media, in art works and literature, Internet-sources and others" [12]. There are such ways: retrospective analysis of vital experience; starting actualization of vital experience of a student, going ahead projection of a teacher, additional constructing, synchronization of educational projections, life analogy, inspiring of objects in holography of educational process, creative synthesis and design of ideal educational objects [2]. The holographic method of projections allows designing an educational process based on life experience of a personality while ignorance is a way to cognition and gaining new experience. Moreover, it allows using the intellectual potential of a personality. Holographic approach in studies is a way to get knowledge in its total fullness. 


\section{RESULTS AND DISCUSSION}

In the context of our research the holographic method of projections gives a student an opportunity to present own vision of work, to focus on aspects that are important for a recipient. Stepping away from a standard interpretation and perceiving it as a hologram allows taking fiction work in its entireness and in a different way. It helps to perceive a text in a new way as well as a literary process and a writer.

We believe that a holographic method of projections is the best variant in the process of working with literature, in particular with literary tales. O.Harachkovska marks: "Literary fairy-tale is an author's fictional work which is marked with brightly expressed fantastic and psychological introspection, personal attitude towards reality and oriented mainly to children (sometimes to adults)". It is written in a way to take into account certain historical and intertextual peculiarities, or at the same time it is literature that adapts folklore texts and retells a folk plot freely enough, however keeping the basic parameters of genre it doesn 't follow folk and poetic tradition [9], [2].

It is the truth that the fairy-tale is one of favorite genres of children and adults. In the process of working with such texts the actualization of life experience, comparisons with the works known before and pushes to create more are possible. Comparing between folk tales and literary tales is possible as well. A "literary tale continues traditions of folk tale in a great deal; in particular taking into account the features of space-time. A literary tale takes for the basis the time of folk tale and develops it by means of author's lexico-grammatical means. Two types of space, namely real and fantastic are common for both folk tales and literary tales. The special space of an author's fairy tale is a psychological space hat shows the way of evolution of fairy tale in the direction of fiction" [6]. The fairy tales of L. Frank Baum (American writer known for his series of books for children about the imaginary land of Oz.) are special in its own way in particular his "American fairy tales" (1901) [1].

This book consists of 12 fairy tales; they are unique in its plot. They are special and characterized by its great wit, cognitive sense and imaginary educational content. The heroes of these fairy-tales are robbers, queens, magicians, models, tangerines and butterflies.

Creation of posters can be one of the options of visualization of fairy tales, for example:

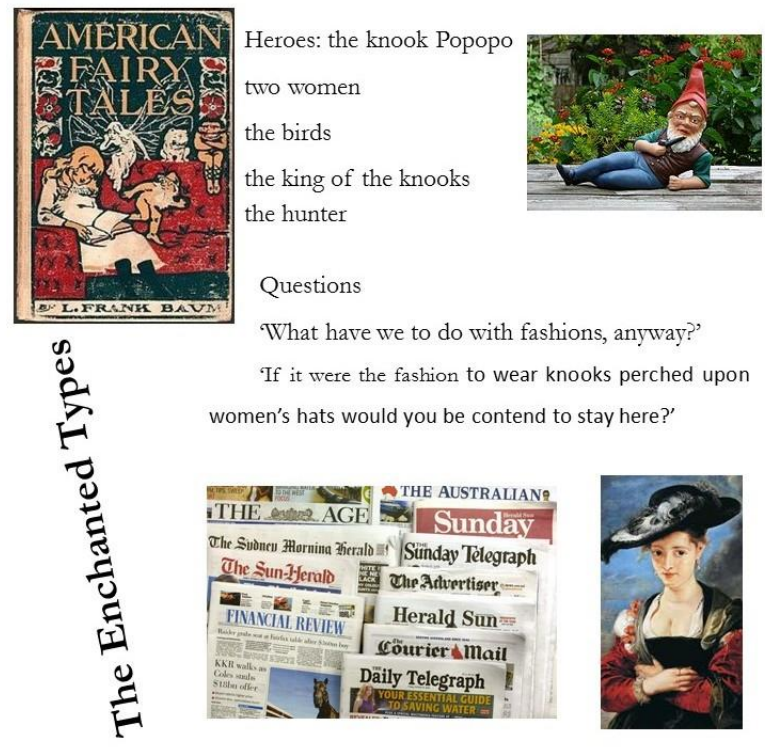

Fig 1. The poster.

Posters may include illustrations to a fairy tale, a list of characters who the students will analyze. The students are supposed to answer the questions and comment the given illustrations. In this way, students show their knowledge of the texts.

Let us consider a few tasks in details. 


\section{Calligrammes}

Calligramme is a poetic form in which the words of a poem are arranged so as to form a pattern suggesting the subject of the poem. The name originates from the collection of poetry Calligrammes: Poems of Peace and War by Guillaume Apollinaire published in French in 1918 (Calligam Design).

In our case Calligramme (graphicriddle) is the description of some text details by using letters of the alphabet, this description helps you to suggest the name of a book. For example:

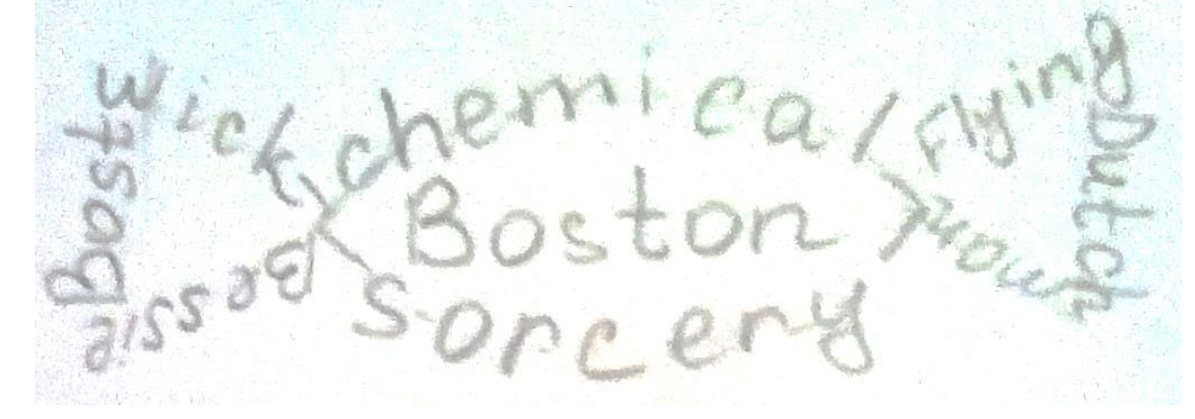

Fig. 2. Calligramme.

The image of a candy is hidden in the following words: Boston, chemical sorcery, Bessy Bostwick, Flying Dutchman. The task is to guess the name of the tale.

It is a fairy-tale - The Magic Bon Bons, where Boston is the place with all the actions of the story, chemical sorcery is a chemical witchcraft, by means of it the magic candies are created, Bessy Bostwick is a girl who takes the candies by chance, Flying Dutchman- is an music overture often played by Bess.

The fairy tale The Capture of Father Time can be represented as a sandglasses, inside of the picture, we can put the names of the heroes or their personal qualities.

The mentioned above tasks teach us to pay our attention to details as they often characterize main characters they also help us to put correct stresses in the reception of the text. A literal detail is "presented by the psychological and speech details that working together become very important" [8]. It is also a "variety of images, a bright detail, a part of the whole work that gives it a special persuasiveness, makes it semantically more valuable, diverse in the content" [8].

It is also important to pay students' attention to the fact that "Calligrammes have a place in the marketing strategies of many companies because they are attractive and can communicate in their own unique way" [4].

The pyramid of the hero is an interesting task as well. Schematically it can be represented like this:

Name of the hero

2 words describing the hero

3 words describing the place of event

4 words describing a problem

5 words describing a plot

6 words that help to think about the event in a new way

7 words that help to solve the problem.

Let us apply this method on the fairy- tale The Glass Dog:

The absence of the name of the main character is the peculiarity of this tale. Therefore, we begin a pyramid with two words:

Glass-blower

Flat, palace, home

Physical beauty, luxurious life

Magic medications, theft of a dog, marriage

The sorcerer gets a dog, a glass-blower gets a beauty

Doggy life of a glass-blower, debts, unhappy wife.

This pyramid can be applied to the author, to the whole text, to main characters as well. It can include both facts and reflections of a recipient concerning the text or author's biography. While 
building these pyramids you are being taught to speak in clear and concrete terms by operating the facts and knowledge of the text.

3) Mind mapping, mental maps "is an easy and effective technique of thinking visualization and alternative record. Mind map is a method of description of general system of thinking process by means of charts. These maps are created for visualization, structure building and classification of ideas, and also as means of studying, organizing, making decisions while writing articles". It is represented graphically in a diagram with words, ideas, tasks given in it. The principle of the "radiant thinking", where a key object serves as a starting point is put in its basis. A great variety of possible associations serves as a peculiarity of the mind map. A mind map is represented in this way.

It can be created by the program https://www.goconqr.com:

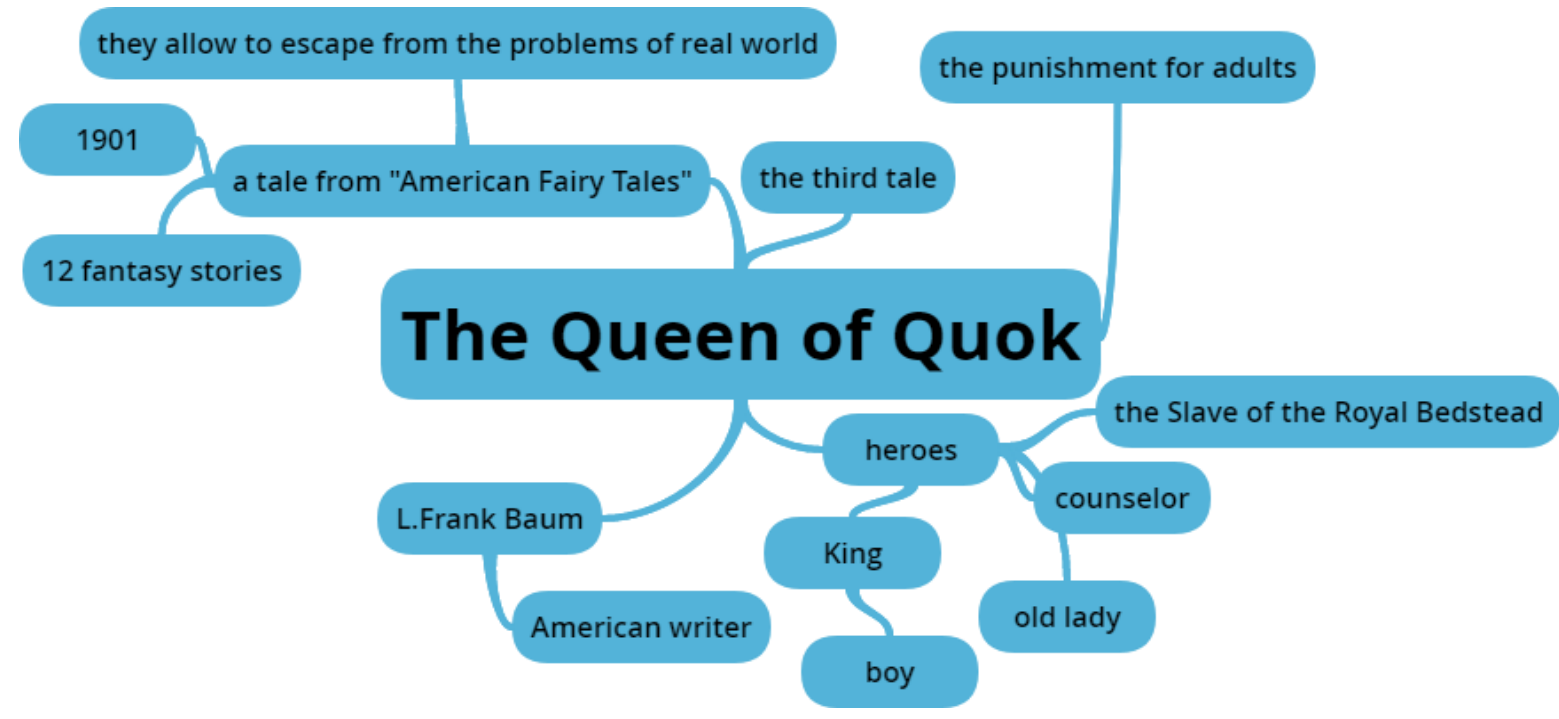

Fig. 3. The mind map.

This is a mind map of the fairy tale The Queen of Quok. It demonstrates a book it is a part of, the author and characters. Drawing of this map can be continued by specifying the basic episodes of writer`s life, personal qualities of the characters and representing a storyline.

The mind map can be applied to literature work, main hero or to key point of a fairy-tale.

We offer to apply a creative game in order to guess the name of the story or the main hero. Let us consider the name of the fairy tale The Box of Robbers: where

B - book which Marta reads

$\mathrm{O}$ - opening the box

$\mathrm{X}$ - $\mathrm{x}$-theme in the attic

$\mathrm{R}$ - right decision

$\mathrm{O}$ - opening the real wish of rubbers

B - brave Marta

$\mathrm{B}$ - best to the rubbers

$\mathrm{E}$ - each rubber is dangerous

$\mathrm{R}$ - rubbers' escape

S - "story should teach us not to interfere in matters that do not concern us" [5].

We consider the method of working with literary tale Six Thinking Hats by Edward de Bono to be very interesting as well.

In its basis, there is a conception of the parallel thinking. Consequently all the impressions of the literary text whatever different they are, coexist, but are not contrasted. Therefore, we have:

Managing Blue - what is the subject? What are we thinking about? What is the goal? Can you look at the big picture?

Information White - considering purely what information is available, what are the facts? 
Emotions Red - intuitive or instinctive gut reactions or statements of emotional feeling (but not any justification).

Discernment Black - logic applied to identifying reasons to be cautious and conservative. Practical, realistic.

Optimistic response Yellow - logic applied to identifying benefits, seeking harmony. Sees the brighter, sunny side of situations.

Creativity Green - statements of provocation and investigation, seeing where a thought goes. Thinks creatively, outside the box.

We can make the hats of required colors or offer the students to imagine them. A student having a blue hat, must outline the aim of text, and express the opinion on the text. A student having a white hat must tell the facts about the author, when it is written etc. A student having a red hat informs us about the attitude to the characters of the tale. A student having a black hat-speaks about the downside of the text and negative emotions caused by it. A student having a yellow hat tell us about the advantages of a tale and positive emotions. A student having a green hat tries to continue the tale on the principle: "And what would it be, if ...?

Let us take the tale $A$ tangerine and a butterfly

A blue hat means the necessity to think about good and evil, true and lie, obedience and disobedience, about senseless service. A white hat should tell us about the author - L. Frank Baum, the American taleteller. It is included in collection of fairy-tales the "American fairy tales"(1901).A red hat makes us think about good characters of the tale and whether he or she forces us to like them. In addition, why is it called a tangerine and butterfly? The searches and thoughts of the butterfly are really touching.

A black hat tells us about the behavior of the butterfly; his obedience and fear can cause irritations. It is vital to think about the phrase: "The butterfly did not reply, but ate the molasses in silence. Having no soul it had no conscience, and having no conscience it was able to lie to the mandarin with great readiness and a certain amount of enjoyment" [1].

A yellow hat tells us that everyone in the tale gets what he or she deserves. It is a moral subtext of the tale. Despite being shy and indecisive the butterfly doesn't insult anybody. A green hat goes on telling the tale in this way: if a butterfly escaped from a tangerine at once, he would remain a man; if a butterfly turned the children into piglets, then it would be a great drama for their parents as they didn't not know where their children had gone. Would there be a fairy tale, if a tangerine and a butterfly did not meet? Would there be a fairy tale without a tangerine or a butterfly?

\section{CONCLUSIONS}

Before offering students to work with the text in the way other than just retelling the content or characterizing the characters, we conducted a small survey in which students had to assess their diligence and attentiveness in reading the work, whether they remember the details, whether they are ready to visualize the work. 


\section{Before working with texts}
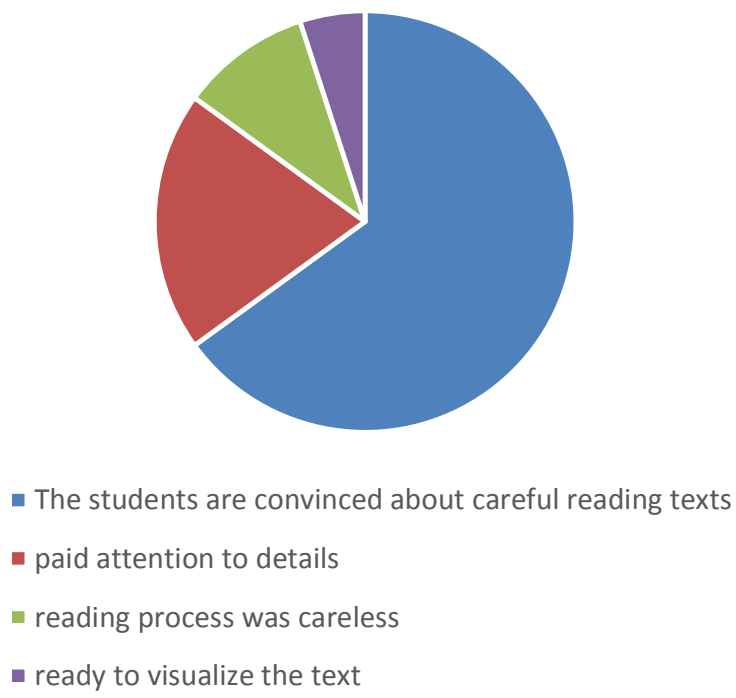

Fig. 4. Before working with texts.

After working with the text, we conducted the same survey, and revealed that most students admitted their reading the text carelessly, without paying attention to details, but many of them were trying to visualize the work on their own. During the semester, we worked with texts using these and other tools of text analysis.

\section{After working with texts}
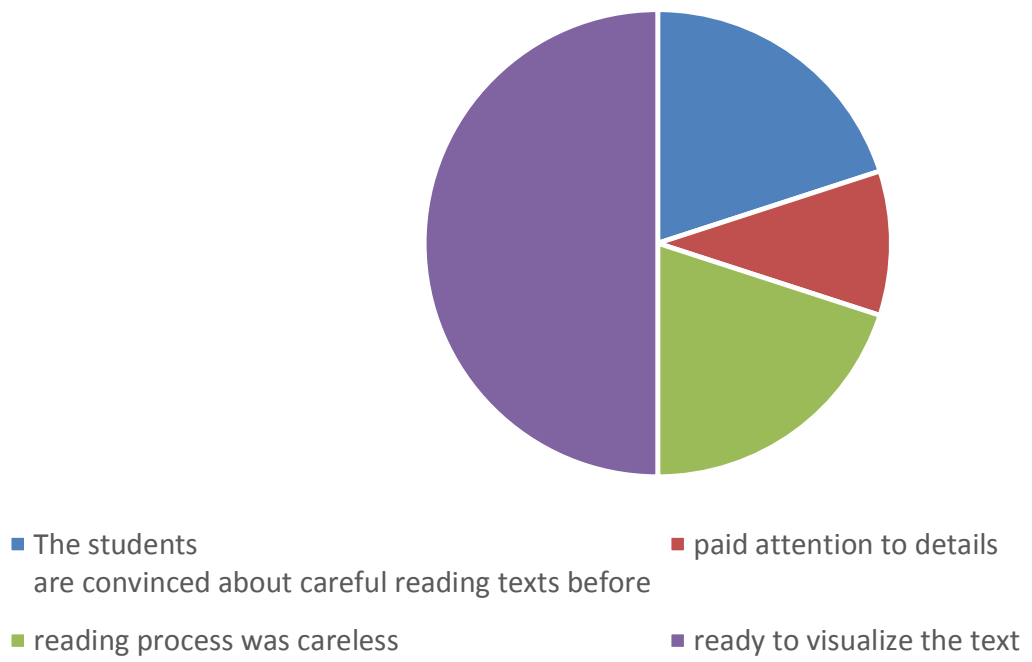

Fig. 5. After working with texts.

Subsequently, the students were offered another survey, all of them had to confirm their readiness and ability to use the method of holographic projections as one of the strategies in text analysis. 


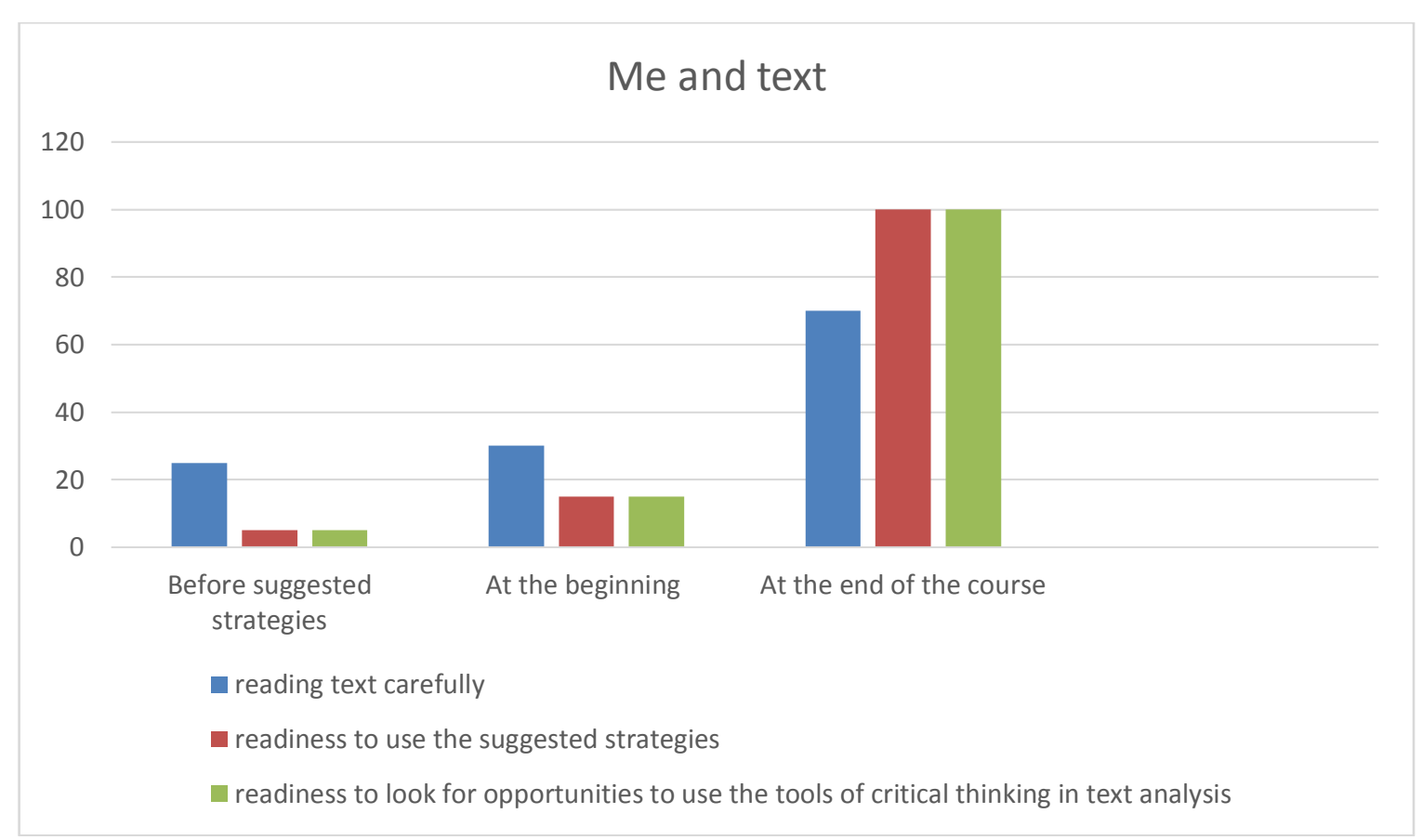

Fig. 7. Me and text.

The students were asked to rate themselves: reading text carefully, readiness to use the suggested strategies, readiness to look for opportunities to use the tools of critical thinking in text analysis.

As we can see from the diagram, after working with texts, the students admitted that they read the text more carefully, that suggested options were clear and possible to use, and most students were ready to search for innovations in working with literary texts.

The demonstrated ways of dealing with literature texts encourage students to work with them persistently and be motivated. Students with different levels of knowledge are supposed to cope with the tasks successfully. Taking into account the demonstrated above material, we can state that holographic technologies support individual students' development, their work and freedom, help them become self-confident and assist to interpret works of literature in a free and deep way.

\section{REFERENCES}

[1] Baum L.F. American Fairy Tales. Kyiv, ZNANNIA, 2013.

[2] Belkin A.S., Verbitskaya N.O. Vitagenic education in the system of pedagogical knowledge (vitagenic concept of personality). Available at: https://cyberleninka.ru/article/n/vitagennoe-obrazovanie-v-sistemepedagogicheskogo-znaniya-vitagennaya-kontseptsiya-lichnosti. (in Russian)

[3] Budnyk O. Innovative Competence of a Teacher: Best European Practices. Journal of Vasyl Stefanyk Precarpathian National University, 6 (1) (2019), 76-89. doi: https://doi.org/10.15330/jpnu.6.1.76-89

[4] Calligam Design. Available at: http://www.lrcommunicationdesign.com/calligrams-graphic-design.html.

[5] De Bono E. Six Thinking Hats: An Essential Approach to Business Management. Penguin, 2016.

[6] Dybovskaya O. Features of chronotope in a literary fairy tale. Philological sciences, 7 (2016), 172-174. (in Ukrainian)

[7] Encyclopedia Britannica. Holography. Available at: https://www.britannica.com/technology/holography.

[8] Kovaliv Yu.I. Encyclopedia of Literature: In two volumes, Vol. 1. Academy, Kyiv, 2007. (in Ukrainian)

[9] Garachkovskaya O. Ukrainian literary fairy tale of the 70s-90s of the 20th century: story-structure, chronotope: thesis for PhD in Ukrainian Literature. Kirovograd, 2008. (in Ukrainian) 
[10] How to Mind Map. Available at: https://www.google.com.ua/search?q=mind+map\&rlz=1C1NHXL_ ukUA761UA761\&tbm=isch\&tbo=u\&source=univ\&sa=X\&ved=0ahUKEwjw6oSOq7TWAhUhLcAKHYu6 CvsQsAQIMQ\&biw=2049\&bih=919\#imgrc=Sc62yzC2EuXcVM.

[11] Kachalova L.P. The method of holographic approach and the process of integration of psychological and pedagogical knowledge of the future teacher. Available at: https://cyberleninka.ru/article/v/metodgolograficheskogo-podhoda-i-protsess-integratsii-psihologo-pedagogicheskih-znaniy-buduschegouchitelya. (in Russian)

[12] Kurland Z.N. Vitagenic technology of formation of professional identity of the future teacher. Science and education, 10 (2014), 111-115. (in Ukrainian)

[13] Mynbayeva A., Sadvakassova Z., Akshalova B. Pedagogy of the Twenty-First Century: Innovative Teaching Methods. In: New Pedagogical Challenges in the 21st Century. Contributions of Research in Education. Available at: https://www.intechopen.com/books/new-pedagogical-challenges-in-the-21stcentury-contributions-of-research-in-education/pedagogy-of-the-twenty-first-century-innovativeteaching-methods. doi: 10.5772/intechopen.72341

[14] Oladapo A. Application of Holographic Technology in Education. Available at: https://www.scribd.com/document/90375851/Application-of-Holographic-Technology-in-Education.

[15] Shepeta A.V. The Use of Vitagen Technologies with the Holographic Projection Method in the Lessons of World Literature. Available at: https://dorobok.edu.vn.ua/article/view/1269 (in Ukrainian)

[16] Vdovenko V. Use of Vitagen Learning Technologies in Mathematics Teaching at School. Scientific Notes of Volodymyr Vinnychenko State Kirovohrad Pedagogical University, 90 (2010), 40-44. (in Ukrainian)

Address: Olga Derkachova, Oksana Tytun, Vasyl Stefanyk Precarpathian National University 57, Shevchenko St., Ivano-Frankivsk 76018, Ukraine.

E-mail: olga.derkachova@pnu.edu.ua; tytunoksana@ukr.net.

Received: 10.01.2021; revised: 18.02.2021.

Деркачова Ольга, Титунь Оксана. Текст як гра: сучасні стратегії роботи з художнім текстом у підготовці майбутніх вчителів (на матеріалі казок $\Lambda$. Френка Баума “Американські казки"). Журнал Прикарпатського університету імені Василя Стефаника, 8 (1) (2021), 155-164.

Стаття присвячена сучасним стратегіям роботи з художнім текстом у процесі підготовки майбутніх учителів, а саме застосуванню їх під час роботи з казками. Запропоновані стратегії дозволяють відійти від традиційного аналізу тексту, запропонувати цікаві інтерпретації, а також зосередитись реципієнту на деталях. Текст оживає, коли отримує нові інтерпретації, а візуальне оформлення доповнюе вербальний зміст. Такі стратегії сприяють підвищенню читацької активності та уважності. Також такий аналіз тестів допомагає розкрити та розвинути аналітичний та творчий потенціал студентів: тлумачити художні тексти, створювати постери, а згодом лепбуки та скрапбуки, що допомагають зацікавити вже маленького читача і стануть у нагоді в подальшій педагогічній діяльності. Прикдадом такої роботи з твором є робота з казками $\Lambda$. Ф. Баума "Американські казки". Ці казки - оригінальне явище американської літератури для дітей, і вони дають чимало простору для різноманітних інтерпретацій. Ці твори яскраві, цікаві та смішні, а відтак текстовий матеріал дозволяе гру з текстом, деталями, персонажами. Звісно, така гра неможлива без уважного читання та розуміння основних ідей тексту. Автори дослідження рекомендують такі методи роботи з текстами як каліграми, піраміда героя, відображення розуму, шість мислячих капелюхів Е. Боно тощо. У результаті такої роботи з художніми текстами, студенти починають уважніше читати твори, звертати увагу на деталі та краще запам'ятовувати певні епізоди. Практично доведено успішність застосування 
таких стратегій у роботі з літературними творами. Таким чином, формуються такі навички, як уважне читання, творче мислення, критичне мислення, здатність відкрито висловдювати думки щодо прочитаного, а також зникає страх неправильної інтерпретації текстів, адже гра текстом дозволяє безмежну кількість інтерпретацій.

Ключові слова: художній текст, стратегія, літературна казка, американська казка, робота 3 текстом, інтерпретація твору. 